\title{
Shifting Society in Response to the Tourism Industry: A Case Study of New Challenges in Lombok Utara
}

\author{
Hasan Basri ${ }^{1}$, Mohamad Tamrin², Dani Alfatwari ${ }^{3}$, Irwan Rahadi4, \\ Muhammad Ramli ${ }^{5}$, Zaitun ${ }^{5}$
}

\author{
Affiliation \\ 1, 5, 6Universitas Hamzanwadi, ' Universitas NagdlatulUlama, Nusa Tenggara Barat, ${ }^{3}$ Virtula \\ School of Hospitality.

\section{Correspondence} \\ Hasan Basri. Universitas Hamzanwadi, Jl. Cut Nyak Dien No.85, Pancor, Selong, Kabupaten \\ Lombok Timur, Nusa Tenggara Barat.Email: hasanbasri@hamzanwadi.ac.id
}

\begin{abstract}
This paper examines shifts in society in response to tourism development in Lombok Utara. This research scientifically demonstrates the emergence of new proble ms due to the social-economic and ecological impact of tourism and the breakdown of tradition. Fishbone analysis was used to map a variety of issues from trusted sources through direct observation and in-depth interviews. Findings show that a gap exists between expected and actual economic advantages as farmers and fishermen transition to tourism. This social challenge has brought severe impacts on local's living. The skill deficit and competitiveness, for example, brought about only a minor effect on the prosperity of host communities, even if a large economic incentive was generated by the government from taxes. The ecological damage resulting from human activity (erosion, rubbish, permanent and semi-permanent buildings, farming shift, coral reef destruction) will be detrimental for future generations. Traditions of the host communities are also threatened.
\end{abstract}

Keywords: Shifting Society; Tourism; Challenges.

Article Information

Submitted 18 Januari 2021 | Revised 30 April 2021 | Accepted 3 May 2021

Recommended Citation: Hasan Basri, H., Tamrin, M., Alfatwari, D., Rahadi, I., Ramli, M., Zaitun. (2020). Shifting Society in Response to the Tourism Industry: A Case Study of New Challenges in LombokUtara. Jurnal Pariwisata Terapan, 4 (2), 183-194.

https://doi.org/10.22146/jpt.63315 


\section{Introduction}

In the very beginning, the tourism industry developed in response to societal economic pressures. This has changed significantly as recreational resources became more abundant, and the comfort of accessibility led to greater local economic advantages (Wang et al. 2020). Indonesia belongs to the N-11 group which is also South Korea and Vietnam. This group has experienced the highest global economic growth (Clyton et al. 2014). Tourism has established a foothold throughout Indonesia, including in the regency of Lombok Utara (Northern Lombok). The tourism industry is considered profitable, and is one of the fastest growing business ventures in the world (Cavallaro, Galati, and Nocera 2017). It has also reduced the rate of poverty (Qin et al. 2019). The World Tourism Organization (UNWTO) released data showing that the recent new growth rate for international tourism of $7 \%$ overshadows the estimated growth target of 3.8\% visitors, and has experienced an upward trend of 5\% in 2018, reaching 1.4 billion arrivals in total (UNWTO, 2018., UNWTO., 2019). This growth has also created new jobs for local residents (Zhang and Gao 2016; Groizard and Santana-Gallego 2018), accounting for 2-12\% of global GDP (Azam et al. 2018). However, some claim that the tourism boom also has a negative impact. It is often responsible for scarcity of resources (Azam et al. 2018), lack of skilled labor (Shu et al. 2018), and influx of job seekers from outside (Tohin Ghosh 2012).

The tourism industry in Lombok Utara has over the past five years grown to almost three times its size in 2016, based on the number of tourist arrivals. In 2016, there were more than three million foreign tourists, while there had previously been only one million visitors, and recreation was the most dominant figure for motivational visits (BPS 2017). Similar data (Kevin, Mengjie, and Wenming 2017) suggests that the contribution of the tourism sector (leisure, recreation, and holiday) reached almost 52\%, and only $14 \%$ of business and professional reasons. Segmentation of arts, culture, history, commodities of the local community, and natural resources made a tremendous contribution for rural communities in terms of employment, alleviating socio-economic gaps (Shu et al. 2018).

Lombok Utara opened to tourism after having formally separated from Lombok Barat (West Lombok regency) in 2008 (Budilestari et al. 2014), leading farmers and fishermen to move to the industrial community. This transition did little to improve the welfare of residents, and according to Cavallaro et al. (2017), it was even associated with new problems, both physical and psychological, although unemployment was reduced and housewives also benefited from increased household income (Ismanto et al. 2012; Qin, Xu, and Chung 2019). New problems, such as knowledge shortcomings in the tourism industry and the participation rate in skilled labor (Andrades and Dimanche 2017) also have implications for poor service and productive worker absorption, triggering skill deficits that require training (Adeyinka-ojo 2018). Ironically, the massive tourism establishment in Lombok Utara did not correspond to the availability of adequate skilled services and the involvement of host communities, possibly because there was no community participation in designing tourism activities, or perhaps due to economic reasons (Digum-aweto, Fawole, and Saayman 2018).

Furthermore, the tourism establishment has resulted in huge land function shifts (Miswanto and Safaat 2018). Land sales are frequent in Lombok Utara. Forest hills lost their ecological protection, and the region was continuously experiencing a decline in wild species conservation as a result of the large-scale construction over exotic accommodation 
replacement. Other changes, such as turning rice fields into parking lots near the coast, threatened agricultural commodity supplies. Henky (2014) mentions intense logging around the tourist venues, including the coastal zone, among the damage caused by the industry, while coastal ecosystems should be national assets for preservation (UNEP 2008). Tourism should be developed so as to have a positive impact on the sustainability of nature; for example, by reducing the economic-ecological impact (Shu et al. 2018), and more importantly, by raising awareness of environmental preservation and of economic protection of income and benefits (Wasonga 2015). Conversely, tourism activities also limit local communities to activities on the coast, because there is protection from the developer to prioritize visitors (Miswanto and Safaat 2018).

On the other hand, challenges for tourism include supporting the economic recovery of coastal areas (Doglu and Bulut 2017). As foreign investors largely controlled the tourism industry, they have eroded the role of host communities, threatening identity loss, and degraded local culture.

This paper discusses new problems in Lombok Utara as a result of the development of tourism, focusing on (1) the transformation of society after the construction of tourism centers; (2) new environmental problems due to tourism development; and (3) the impact on community traditions.

\section{Literature Review}

\section{Shifting society toward tourism industry}

The results of a community's shift toward the tourism industry have been discussed in previous research papers. The rapid urbanization (Stavros et al. 2016) due to tourism is common, considering the availability of job vacancies, even though it requires competitive skills. Increasing human needs encourage a dramatic move toward business factors for fulfillment of basic needs (jobs). Globalization, as a process of migration, has created an international labor market leading to an income flow of immigrant origins (Mora-Rivera, Ceron-Monroy, and Garcia-Mora 2019). Laksahmi and Shaji (2016) argue that intervention in the form of urbanization in coastal areas is associated with environmental damage. However, the results of Ismanto, Huda, and Maulida (2012) show that tourism had a positive impact on employment and benefited housewives, who could earn a living at home.

Job opportunities from the tourism sector actually help the poor to fulfill daily needs through income from labor. On the other hand, redistribution of revenue from tourism activities helps lift the community's economy (Qin, Xu, and Chung 2019). The intensity of the work, leading to more jobs, indirectly encourages the initiative of entrepreneurs to expand the tourism business, which tends to damage the physical environment (Brtnicky et al. 2020).

The advent of the tourism industry in the community affects not only the economy, but also the community's social and cultural life. Tourism is identical with the social hub. It constitutes the meeting point of different educational backgrounds, social cultures, and lifestyles, causing major changes resulting in adaptation, assimilation, acculturation, and even the dominance of a particular group. For socio-cultural reasons, tourism may lead to global capitalism (Wasonga 2015) or create individualism, resulting in the destruction of the 
value of local community solidarity. Long-established cooperative values can fade from cultures. This can happen because the tourism industry creates an economic-oriented advantage rather than social advantages. Socially, a value of transition occurs as a result of multi-directional interaction. Collaboration between tourists and local people changes behaviors, kinship relationships, and social structure. The frequency of intense interactions has implications for cultural imitation and adoption, which are sometimes unacceptable. Hotel and tour operators and travel agents contribute to the negative social impact. Obvious examples are increased begging, crime, gambling, and the devaluing of the local language (Mccombes, Vancley, and Evers 2015). On the other hand, such social interaction brings the changes of people's behavior to cultural openness.

In almost all main destinations, tourism is driven by economic interests. Entrepreneurs and investors help create jobs for locals, although sometimes only in non-strategic positions. The move of community professions from farming and fishing into tourism industry actually sparks dilemma. As in many tourism zones in Indonesia, the local people of Lombok face a very hard choice. On one hand, they want to get a decent job with a sufficient salary that can meet the needs of their families, while limited skills force them to work as unskilled laborers. On the other hand, the changes in job availability around tourist destinations have led to social divisions. Competition for vacancies is the most common reason, in addition to managers' tendency to hire outside workers rather than locals (Gosh 2012).

Socio-cultural aspects of tourism are often overlooked. The migration of people who choose to work in tourism has resulted in reduced human solidarity. This leads to a change in values, where materialism and individualism become very strong in the community. Habits of sharing with neighbors, caring for the environment, and local wisdom begin to be abandoned. Social cohesiveness is slowly giving way to hedonism. Although the tourism industry reduces poverty (Qin, $\mathrm{Xu}$, and Chung 2019), the negative effects of tourism must be balanced with policies of protection and welfare assurance.

Problems from shifting of prevalent professions often spill over into social phenomena. New problems can be bewildering. The employment opportunities are varied and broad. If the destination managers collaborate professionally, employing local residents as skilled workers, the imbalance of work positions would not cause problems. Furthermore, the move of professions away from farming and fishing is not always risky. Residents can be employed in important positions if they have the skills needed by the company. However, tourism establishments such as hotels employ mainly outside workers (Gosh 2012). The companies argue that this is necessary to ensure customer satisfaction. However, some people claim that the recruitment of staff from outside is simply a way for the company to cut operational costs: it would have been more expensive to train local people whose existing skills are unsuitable. The company prefers applicants who already have the required skills.

\section{Challenges in Tourism}

As the tourism industry continuously grows, the influx of tourists has a dramatic impact on the lives of the surrounding community. With the help of the information technology, which is rapidly benefiting tourism (Brant, Bendler, and Neumann 2017), freedom of exploration and activity enables tourists as migrants to exchange insights and behaviors. An exchange of 
clothing styles and cultural acculturation with the local community are inevitable. The process of mixing or assimilating from a variety of different backgrounds presents a strong challenge for locals who do not reflect their habits. This is common among local communities without generating serious conflict. Research conducted in rural China by Wang and Yotsumoto (2019) has identified the main conflicts, including land exploration, vending rights, and house demolition. Other problems, such as ticket revenue distribution and waste generated by tourism (attribute. e.g tourism activities, tourism industries, etc.), contribute to dynamic conflicts that disturb the harmony of the environment and social order.

The tourism industry is also associated with serious environmental problems. Budilestari, Hutomo, and Ardiwidjaja (2014) criticized unprocedural activities associated with physical tourism infrastructure. Deforestation for accommodations, in the form of cutting down mangroves near the coast, has generated disastrous coastal erosion, which threatens the potential recreational locations (Phillips and Jones 2006). Destruction of coral reefs also occurs. Activities such as sand mining and road expansion contribute to erosion (AlcantaraCarrioand Cabrera 2002). These illegal activities not only destroy most of the marine life, but also endanger the fishermen's livelihoods in the long term.

Land function change (Miswanto and Safaat 2018) for the expansion of accommodation development in hilly zones has shifted people's livelihoods from farming to industrial society (tourism). Massive tree logging on various picturesque hills offering a view of the sea, and the construction of new buildings such as villas, bungalows, and hotels on agricultural land limit the land available for farming and have led to the emergence of a job shift. Residents of coastal communities who had previously worked as farmers can also work as fishermen at sea at night. The mining of coral reefs, widening of coastal erosion, reduction in locations for farming and fishing are all direct economic effects of tourism. Interestingly, supporting research conducted by $\mathrm{Li}$, Bai, and Alatalo (2020) suggests that tourism has caused a reduction of agriculture and forest mainly through conversion to construction sites.

Furthermore, tourism affects social life. The development of the tourism industry tends to create income inequality (Scott, Simpson, and Sim 2012) because of unskilled labour (Haija 2011). Another effect is the lack of local community participation (Digum-aweto, Fawole, and Saayman 2018) as the potential of tourism to strengthen the economy, raise aware ness of environmental values, and offer financial protection is not realized (Wasonga 2015). Interestingly, research conducted in Lombok by Saufi, O'Brien, and Wilkins (2014) explained in detail that the main challenge of tourism is the lack of coordination among tourism agents, developers, the private sector, and the needs of local communities. Developers should promote education as an agent of change (workshops, tourism training), enhancing skills and knowledge; these potential resources have largely been exploited (Gosh 2012).

In regard to culture, the development of the tourism industry has caused tremendous negative changes to society, lifestyle, and cultural values (Thanvisitthpon 2016). Overdevelopment drives social problems such as cultural destruction, overcrowding leading to traffic congestion, and the decline in quality of life (Wang et al. 2020). Rural tourism trends, for example, have a strong effect on the socio-cultural life of the community. Changes in 
behavior due to mutual interaction slowly shift the social values, leading to the fading of collective values.

The intensity of interaction between tourists and local people has slowly shifted the traditional regulations and patterns of life. This shift has encouraged the fading of cultural values such as the mutual tradition. As people no longer feel that they can rely on others for help, an attitude of individualism sets in, where competitive consumerism emerges as the dominant trait. The tourism industry creates a new lifestyle. This is most noticeable in the clothes and appearance of the local people, who begin to imitate the habits of the tourists. The influence of social interaction has emerged local traditions. The direction of cultural regeneration is not constructive. Unlike traditional local values, tourism prioritizes economic development, property expansion, and entrepreneurial orientation, ignoring the quality of life, emotions, stress and other psychological effects on the residents (Jordan, Spencer, and Prayag 2019).

However, the impact of tourism is not entirely negative, as previously stated by researchers. Although tourism can worsen the image of local traditions, environmental impact (Kurniawan et al. 2019), it can also generate interest in reviving local cultures in danger of disappearing. This has been observed in many destinations, where cultural revival is used to attract visitors.

\section{Methods}

A case study with a descriptive-qualitative approach was used for this research. We analyzed the findings using the fishbone method, emphasizing the shifts in society and outlining the causal relationships of new problems involving the tourism industry. Basically, the fishbone is cause and effect used for methods of identifying the root of problems. As previously stated, the advent of tourism (cause) created challenges (social, environment and breakdown of tradition) to host society. The fishbone enabled all data mapped and analyzed in details for high trustworthiness. We collected data, however, from two categories, primary and secondary data, over seven months in Lombok Utara. Primary data was collected through observation over several months since the researchers were key witnesses and lived in the research location. To collect other data, in-depth interviews were conducted with interested parties such as the head of the Tourism Office, community leaders, tour guides, and the tourism business developer. Secondary data was collected from documentation literature and official tourism information in Lombok Utara, BPS (central bureau of statistics), and other relevant sources.

\section{Results and Discussion}

Tourism generates key revenues for Lombok Utara. Tourism has led to the construction of new buildings, permanent and semi-permanent, in certain potential zoning areas, especially around the coast and on three islands, Terawangan, Air, and Meno, which are the main tourism objects. After North Lombok (Lombok utara) officially split up in 2008 , it opened to tourists through efforts by both the government and host communities, starting with the construction of road infrastructure and new tourist accommodations. The idea of building tourist venues in quantity brings tax revenue, while also triggering serious disagreements over people's behavior, traditions, and ecological damage. 


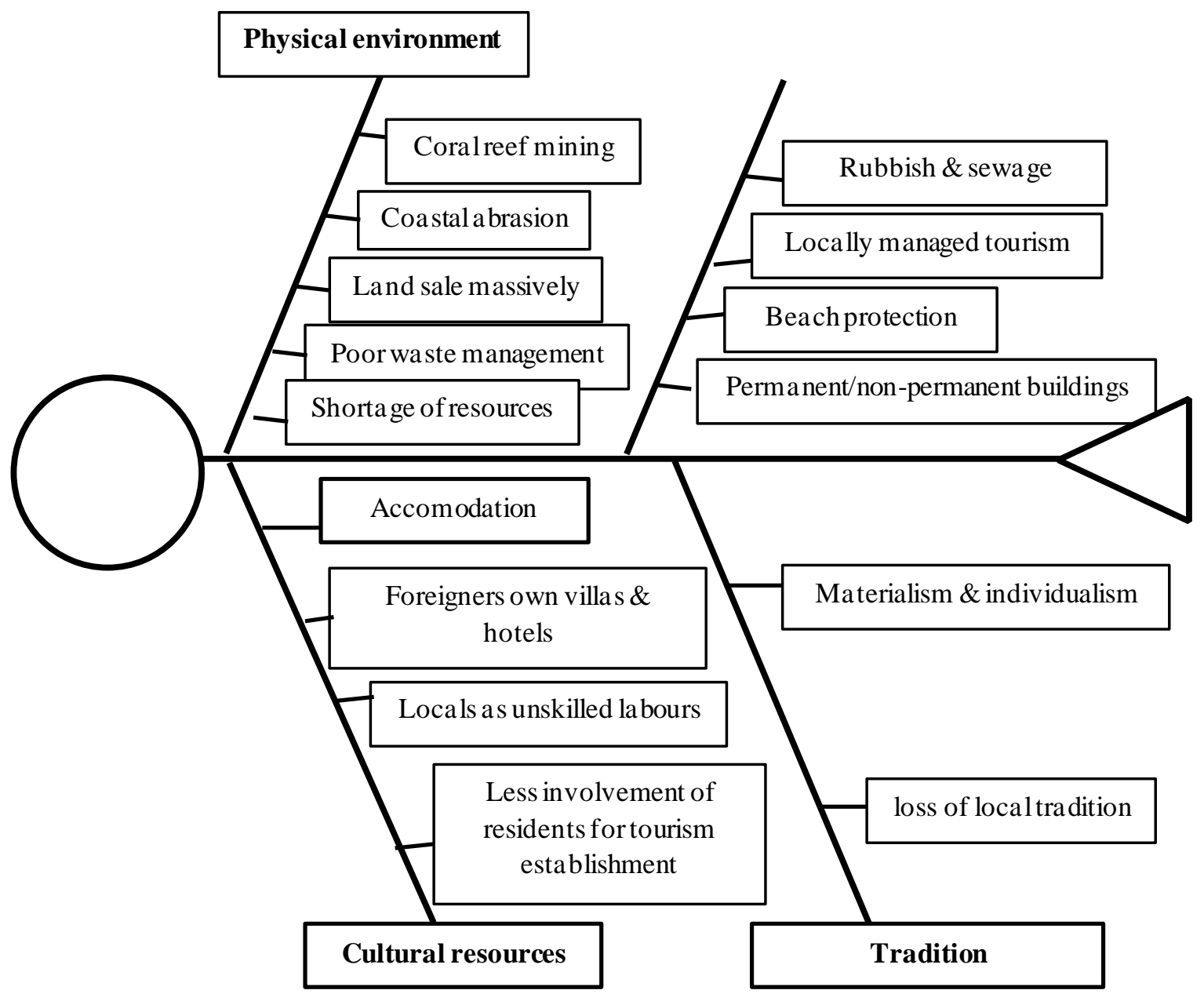

Figure 1: Fishbone Analysis

\section{Social shift and its problems}

Fishbone analysis during data collection shows the complexity of problems. The social problems are significant challenges for host society which are absolutely stemming from the relocation of farmers and fishermen to industrial communities. The dominant factor behind this mobility was the promise of business opportunities. Consequently, in the early 2000s, the host community sold land on a massive scale to investors, as they also hoped to become business players. Moreover, the land prices were low. This could capital holders easily take over the land. The Teluq Kodeq village, for example, near the Kelui village on the western border, with land around the coast and hills, has been controlled successfully by investors or other parties (businessmen). However, the movement of host communities can lead to new problems. The skills deficit was one of the main reasons for developers not to massively employ the locals although they had promised host-society for proper jobs. On the other hand, inexperienced people who had already sold their land with inadequate experiences faced a dilemma. They filled unskilled labor positions as cleaning service providers for 
gardeners, parking attendants, and boatmen. Additionally, the role of the host communities was limited to the management of the tourism objects whose access to the beach is limited to local communities.

This is almost the same as what has happened in the Bakau Bay of the Riau Archipelago. The construction of the accommodation business threatens the green open spaces, while coastal protection is reduced by almost $80 \%$ by the developers. Moreover, entreprene urs are only materialistically, not interested in host society empowerment. In terms of the social impact, tourism creates vulnerability to crime, as well as an increase in untreated garbage, which affects pollution (Miswanto and Safaat 2018). Other changes in the host society include environmental pressures, such as increasing noise, biodiversity loss (Zhang and Gao 2016), resource scarcity, and child labor (Azam, Alam, and Hafeez 2018). Therefore, government policies must pay close attention to four things: planning, development, policy, and regulations. According to Joseph Wasonga (2015), tourism development may have devastating effects on the environment if not well regulated.

A related interview quotation is included.

\begin{abstract}
"AR: It is true that tourism createsjobs. But for us, it actually limits our space to make a living. Before the massive development of tourism, we were able to catch fish along the coast. Now, there are restrictions from the hotel developers because of the convenience of the visitors. Also, the fishing catch is not as good as before, maybe because of the frequency of disposal of fuel and coral mining activities for building materials."
\end{abstract}

\title{
Impacts of community traditions
}

It cannot be denied that the progress of tourism has changed traditional societies. The advent of the tourism industry in North Lombok has massively an impact on the transformation of the daily routine of the host society, which from the start is generally fishing, farming and gardening communities. This has resulted in the loss of a cultural ritual such as; Nyelametan Telukan. The Nyelametan Telukan is a ritual of salvation which has the meaning of a ritual of gratitude for seafood defenses as well as environmental conservation. This belief is often found in communities on the north coast of Lombok (Lombok utara), for example in Kecamatan Kecinan, Teluk Kombal and Mentigi before the construction of tourism. Today, such tradition hardly exists since tourism activities operated. The massive flow of tourism has changed local habits, and one of them is Nyelametan Telukan which formerly became crucial tradition. On the other hand, a materialistic society has also been formed which has an impact on the pragmatic view of society along with tourism activity.

The development of a local-wisdom-based tourism is one solution that may stem the tide of lifestyles influenced by tourism. The only practical way to do this is to revive the local attractions that have almost been abandoned by the community in the form of cultural shows, which would of course become a robust base for the development of the localwisdom-based tourism industry.

\section{Physical environmental problems}

Another crucial problem was erosion. The shrinking of the shoreline around tourist attractions in Lombok Utara was caused by several factors: the logging of trees on the coast, such as mangrove, pandanus, and coconut trees, which have the protective function of water absorption; the low coastal plains below; the proximity of resort properties to the 
coastline; and the infrastructure positioned very close to the coastline (Scott, Simpson, and $\operatorname{Sim}$ 2012).

The construction of new hotels and other lodgings is the primary reason for the decrease in mangrove trees on the waterfront. Villa and restaurant buildings stand tall along the shoreline, replacing thick trees such as mangroves, even though the construction is against the law. These illegal buildings naturally have a negative impact on natural events, such as the increased danger of coastal erosion over time. To date, the three islands, Gili Trawangan, Gili Air, and Gili Meno, have experienced significant land shrinkage, about 1 to 2 meters from the shoreline. This has still not received serious attention from the government. Garbage is also still discussed among the community and environmentalists.

Other factors, such as mining coral reefs for building materials, have exacerbated environmental damage. Coral mining in the sea has occurred in the village of Malacca, involving several other villages, such as Mentigi, Pandanan, and Kecinan. The surrounding community mines the coral when the sea water begins to recede. They bring all necessary equipment, such as hammers and hard-sized sacks. Large areas of breeding grounds of fish and other marine creatures are endangered. This illegal activity is most severe in the village of Nipah. The reefs there no longer functioned as large wave breakers that could prevent the village from destruction (Budilestari, Hutomo, and Ardiwidjaja 2014). This will also lead to long-term damage of the underwater ecosystem. The following paragraphs are interview notes.

\footnotetext{
"We got a few facts on the ground, that is, there is a lot of logging practiced by loc al people around the coast, and destruction of coral reefs to meet the needs for building materials, and abundant coral reefs have faded due to the use of potassium and explosives to catch fish. This was huge in the 2000s, so it had a negative impact on the underwater ecosystem."

"Tl: Over the past 5 years, our village has been getting hotter. We have seen the number of mangroves and other trees along the beach decreasing. Villa, bungalow, and hotel buildings have changed the function of the trees, even though this is against the law where buildings may not stand on shoreline."
}

Furthermore, the problem of waste from tourism objects affects the convenience of visitors. The shortage of waste processing facilities and the lack of organization in dealing with waste problems in the community remains a serious problem. Host communities can work together or cooperate with the government to solve this problem and minimize uncontrolled trash.

Almost all vital sectors (tour operators, airlines, hotel owners) are monopolized by elite groups, causing money to flow to outsiders. Local people receive only small benefits. The environment has been disturbed and destabilized by lodging, waste, and mining coral reefs. Local wisdom is in decline, and may continue to weaken if there is no initiative for a better solution.

\section{Conclusion}

The profession movement of farmers and fishermen into the tourism industry has created a wide range of serious problems. The sale of land to developers has harmed the locals. The decision to move into tourism industry did not make them better off economically; instead, 
it has caused problems. As the seashore has been privatized, the locals' access to it has been restricted, leaving them unable either to make a living from fishing or to appreciate the beauty of the beaches. Such problems are mostly created by unskilled locals (skill deficits) and limited capital which drove them in non-strategic position as unskilled laborers. At the same time, ecological changes due to land use have resulted in damage such as erosion. Garbage is a problem, in addition to other damage, such as reduced agricultural land, which determines the availability of food stock. To make it clearer, soft-skill training toward locals must be addressed both by local government and industry providers (hotels, homestay, villa, bungalows) in relation to reducing social and environmental problems. In addition, regular outreach on environmental conservation to the community can increase individual awareness of wildlife survival.

\section{References}

Adeyinka-Ojo, S. 2018. A strategic framework for analyzing employability skills deficits in rural hospitality and tourism destinations. Tourism Management Perspective 27: 47-54

Alonso, J., J., Alcantara-Carrio, and L. Cabrera. 2002. Tourist resorts and their impact on beach erosion at Sotavento Beaches, Fuerteventura, Spain. Journal of Coastal Research-International Coastal Symposium (ICS 2002) 36: 1-7.

Andrades, L. and F. Dimanche. 2017. Destination competitiveness and tourism development in Russia: Issues and challenges. Tourism Management 62: 360-376

Azam, M., , M.M. Alam, and, M. H. Hafeez. 2018. Effect of tourism on environmental pollution: Further evidence from Malaysia, Singapore and Thailand. Journal of Cleaner Production 190: 330-338

BPS (Statistical Central Bureau). 2017. Tourist Arrivals, viewed 27 October 2019, ntb.bps.go.id

Brant, T., J. Bendler., and, D. Neumann. 2017. Social media analytics and value creation in urban smart tourism ecosystems. Information and Management 54, (6): 703-713

Brtnicky, M., V. Pecina., M.V. Galiova,. L. Prokes..., J. Kynicky. 2020. The impact of tourism on extremely visited volcanic island: Link between environmental pollution and transportation modes. Chemosphere 249: 1-8.

Budilestari, N., M. Hutomo., and, R. Ardiwidjaja. 2014. Permasalahan Lingkungan di Sempadan Pantai Taman Wisata Perairan Gili Trawangan, Nusa Tenggara Barat. Jurnal Kepariwisataan Indonesia 9: 91-107

Cavallaro, F., O.I. Galati., and S. Nocera. 2017. Policy strategies for mitigation of GHG emissions caused by the mass-tourism mobility in coastal areas. Transportation Research 27: 317-324

Clyton, A.H., I.A. Ajagunna, and F.H. Pinnock. 2014. Tourism in a transforming world economy - the impacts of the brave new world: How might Jamaica achieve longterm sustainable development? Worldwide Hospitality and Tourism Themes 6(2): 191-196

Digun-Aweto, O., O.P. Fawole, and M. Saayman. 2018. The effect of distance on community participation in ecotourism and conservation at Okomu National Park, Nigeria. Geo Journal, 1-15

Dogru, T., and U. Bulut. 2017. Is tourism an engine for economic recovery? Theory and empirical evidence. Tourism Management 30: 1-10 
Ghosh, T. 2012. Sustainable coastal tourism: Problems and management options. Journal of Geography and Geology 4(1):16-169

Groizard, J.L., and M. Santana-Gallego. 2018. The destruction of cultural heritage and international tourism: The case of Arab countries. Journal of Cultural Heritage, 33:285-292

Haija, A.A.A. 2011. Tourism and conflict with local communities. Habitat International 35: 93-100

Hengky, S.H. 2014. Excogitate coastal tourism competitiveness by implementing ecotourism in Anyer, Banten, Indonesia. International Journal of Marine Science, 4: 7481.

Ismanto, K., H. M. Huda, and C. Maulida. 2012. Transformasi Masyarakat Petani Mranggen Menuju Masyarakat Industri. Jurnal Penelitian 9: 35-48

Jiang, Y. and B.W. Ritchie. 2017. Disaster collaboration in tourism: Motives, impediments and success factors. Journal of Hospitality and Management 31: 70-82

Jordan, E.J., D.M. Spencer, and G. Prayag. 2019. Tourism impacts, emotions and stress. Annals of Tourism Research 75: 213-226

Kevin, X. L., J. Mengjie and S. Wenming. 2017. Tourism as an important impetus to promoting economic growth: A critical review. Tourism Management Perspectives 26: $135-142$

Kurniawan, F., L. Adrianto., D.G. Bengen., and L.B. Prasetyo. 2019. The social ecological status of small islands: An evaluation of island tourism destination management in Indonesia. Tourism Management Perspective 31: 136-144

Laksahmi, S. R. and T. L. Shaji. 2016. Transformation of coastal settlements due to tourism. Procedia Technology 24:1668-1680

Li, J., Y. Bai, and J.M. Alatalo. 2020. Impacts of rural tourism-driven land use change on ecosystem services provision in Erhai Lake Basin, China. Ecosystem Services 42: 1-10

McCombes, L., F. Vancley, and Y. Evers. 2015. Putting social impact assessment to the test as a method for implementing responsible tourism practice. Environmental Impact Assessment Review 55: 156-158

Miswanto and M. Safaat. 2018. Dampak pembangunan industri pariwisata terhadap alih fungsi lahan. (Studi tentang kehidupan sosial budaya masyarakat desa Teluk Bakau, kecamatan Gunung Kijang, kabupaten Bintan, Kepulauan Riau). Jurnal Antropologi 20: $45-55$

Mora-Rivera, J., H. Ceron-Monroy., and F. Garcia-Mora. 2019. The impact of remittances on domestic tourism in Mexico. Annals of Tourism Research 76: 36-52

Phillips, M.R. and A.L. Jones. 2006. Erosion and tourism infrastructure in the coastal zone: Problems, consequences and management. Tourism Management 27: 517-524

Qin, D., H. Xu, and, Y. Chung. 2019. Perceived impacts of poverty alleviation tourism policy on the poor in China. Journal of Hospitality and Tourism Management 41: 41-50

Stavros, S., S. Fani, T. Stergios, S. Ioannis., and C. Olga. 2016. The environmental pressures and perspectives of tourism on coastal and ansularzone: The case of Greece. Natural Environment and Pollution Technology 15: 1009-1020.

Saufi, A., D. O'Brien, and H. Wilkins. 2014. Inhibitors to host community participation in sustainable tourism development in developing countries. Journal of Sustainable Tourism 22: 801-820 
Scott, D., M.C. Simpson, and R. Sim. 2012. The vulnerability of Caribbean coastal tourism to scenarios of climate change related sea level rise. Journal of Sustainable Tourism 20: $883-898$

Shu, Y.P., G. Mengyao., K. Hyunook., J.S. Kinjal., L.P. Si and C.C. Pen. 2018. Advances and challenges in sustainable tourism toward a green economy. Science of the Total Environment 635: 452-469

Thanvisitthpon, N. 2016. Urban environmental assessment and social impact assessment of tourism development policy: Thailand's Ayutthaya historical park. Tourism Management Perspective 18: 1-5

UNEP. 2008. Disaster Risk Management for Coastal Tourism Destinations Responding to Climate Change.https://www.onecaribbean.org/wp-content/uploads/Disaster-RiskManagement-Coastal-Tourism-UNEP-CAST.pdf

Wang, J., X. Huang., Z. Gong., and K. Cao. 2020. Dynamic assessment of tourism carrying capacity and its impacts on tourism economic growth in urban tourism destinations in China. Journal of Destination Marketing and Management 15: 1-15

Wang, L., and Y. Yotsumoto. 2019. Conflict in tourism development in rural China. Tourism Management 70: 188-200

Wasonga, J. 2015. National heritages, global capital accumulation and collective socioeconomic impact: A critique of tourism industry in Kenya. Journal of Tourism Challenges and Trends 8: 55-77.

World Tourism Organization (2018), UNWTO Tourism Highlights. United Nations World Tourism Organization.

World Tourism Organization (2019), UNWTO Tourism Highlights. United Nations World Tourism Organization.

Zhang, L., and J. Gao. 2016. Exploring the effects of international tourism on China's economic growth, energy consumption and environmental pollution: Evidence from a regional panel analysis. Renewable and Sustainable Energy Reviews, 53: 225234 